\title{
Peertechz
}

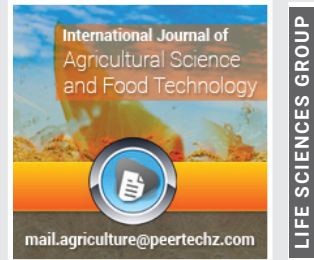

\section{Suitability of bio-extracts} with coating materials on physicochemical quality of tomato fruits (Solanum Lycopersicum L.) stored at ambient temperature

\author{
Desta Dugassa Fufa*
}

Received: 27 July, 2021

Accepted: 09 November, 2021

Published: 10 November, 2021

*Corresponding authors: Desta Dugassa Fufa, Department of Food Science and Postharvest Technology, Haramaya University, Ethiopia, Tel: +251923797359; Email:ddestaman@gmail.com

Keywords: Ambient temperature; Bio-extracts; Edible coating; Quality; Storage; Tomato

Copyright: @ 2021 Fufa DD. This is an open-access article distributed under the terms of the Creative Commons Attribution License, which permits unrestricted use, distribution, and reproduction in any medium, provided the original author and source are credited.

https://www.peertechzpublications.com

\section{Check for updates}

Department of Food Science and Postharvest Technology, Haramaya University, Ethiopia

\begin{abstract}
Tomato (Solanum Lycopersicum L. (or) Lycopersicon esculentum Mill.) is being a very nutritious and health protective food, are highly perishable nature. Its sensitivity to postharvest loss due to poor handling, diseases and physical injury limits its successful marketing. Therefore, simple technology is required to reduce the postharvest loss of this commodity. The use of edible coatings with bio-extracts appears to be a good alternative preservation technique to extend the mature tomato fruits. This study was, therefore, initiated to investigate the effect of using bio- extracts garlic bulba and capsicum incorporation with coating materials (maize starch and beeswax on physicochemical quality of tomato fruit stored at ambient conditions (temperature 15.5 to $20.2^{\circ} \mathrm{C}$ and relative humidity of 55.5 to $67.3 \%$ ). The experiment was conducted using complete randomized design of two varieties (Fetane and Melkashola) and six treatments. The tomato fruits were coated by dipping into solution for 3 minutes. The treatments prepared were on coating solution of MGE( $9.5 \%$ maize starch with $0.5 \%$ garlic extract), MCE (9.5\% maize starch with $0.5 \%$ capsicum extract), BCE (9.5\% beewax mixed with $0.5 \%$ capsicum extract), BGE ( $9.5 \%$ beewax mixed with $0.5 \%$ garlic extract), $10 \%$ maize starch without bio-extract, $10 \%$ beewax without bio- extract and control. The treatment means were tested at significance level of $P \leq 0.05$. The effectiveness of bio-extracts with coating materials on physicochemical quality of tomato fruits were evaluated at three days intervals for 30 days. There was a significance difference $(P<0.05)$ between coated and uncoated fruits. All coatings delayed tomato ripening and improved the keeping quality parameters but best results were exhibited by $9.5 \%$ with $0.5 \%$ BCE followed by $9.5 \%$ with $0.5 \%$ MGE by maintaining the mature tomato fruit for 30 days. The study showed that the Fetane variety has maintained more quality attribute than Melkashola variety during storage.
\end{abstract}

\section{Introduction}

Tomato (Solanum Lycopersicum L. (or) Lycopersicon esculentum Mill.) is considered as one of the most important and known vegetables in the world. By weight, tomatoes rank second only to potatoes in global production of all horticultural produce of high yielding, better adaptability and multipurpose uses for instance, it can be eaten in various ways and in a countless number of dishes. And also eaten raw in salads or as an extract or sauce in many dishes and in drinks [1]. Globally, tomato production accounts 162 million tons from about 4.8 million hectares of land area [2].

This fruit is one of food sources rich in micronutrients that are necessary for health benefits include reduced risks of cancer, skin health and cardiovascular disease. Therefore, tomato is known for its outstanding nutritive and medicinal values and therefore grouped under protective foods $[3,4]$. Despite numerous nutritious and health benefits of tomatoes, storage life have being limited by several factors including physiological losses and senescence, biological factor, physical or mechanical injuries, and environmental condition. Uneven handling of tomatoes can also result in the damage of the fruit cell wall leading to softening, and increased respiration which results in faster fruit ripening and deterioration of fruit quality and reduced marketability of the product [5].

Kitinoja and Gorny [6]. Reported that fresh fruits and vegetables are perishables and their postharvest losses are estimated to be 5 to $25 \%$ in developed and $20 \%$ to $50 \%$ 
developing countries. Due to postharvest diseases and poor management system, it accounts approximately $20 \%$ of the annual world production of tomato fruit is lost, particularly those caused by pathogenic fungi losses in tomato fruits stored in poor conditions especially under high temperature [7].

Several postharvest interventions have been introduced to help maintain quality and extend storage life. These interventions include low temperature storage, edible coating, and modified atmosphere packaging. The combinations of treatments such as low temperature, coatings, low oxygen and high carbon dioxide storage and ethylene inhibitor such as calcium chloride treatment have been reported to have the potential to extend the storage life of fresh produce such as tomatoes [8].

In Ethiopia, growing and marketing of fresh produce is complicated by high postharvest losses in quantity and quality between harvest and consumption which is estimated to be in the range of $20-45 \%$ [9]. According to Mohammed and Afework [10]. The average annual postharvest of tomato is estimated to be $45 \%$. This high loss is due to improper use of packaging materials, postharvest diseases, physiological factor, storage facilities and poor care during transportation such as by human labor, donkeys and mules, public transport and rented trucks [11].

As result, there is a huge gap between production and consumption of fresh produce in the country due to considerable postharvest loss. This is typically of tomato fruits and requires the use of different methods to reduce the losses. One of the methods is the use of coating materials on fruits and applying anti-microbial substances use of wax materials and starches for coating fruits have been practice quite for same time, but their use in combination with bio- extracts have not been tried for preservation of local produce. This study used for producer, wholesaler, and food processor at large level. Generally, the purpose of this study was to investigated the of use natural bio-extracts by incorporation with coatings materials to extend the shelf life of the mature tomato fruits at ambient condition.

\section{Method and materials}

\section{Experimental location}

The experiment was conducted at Haramaya University. The Haramaya University is located at an altitude is about 1980 metres above sea level, latitude of $9^{\circ} 26^{\prime} \mathrm{N}$ and longitude of $42^{\circ} 03^{\prime} \mathrm{E}$. The mean annual temperature is $17^{\circ} \mathrm{C}$ with the average minimum and maximum temperature is $8^{\circ} \mathrm{C}$ and $24^{\circ} \mathrm{C}$, respectively. The mean relative humidity is $50 \%$, varying from $20-80 \%$ [12]. Evaluation of quality parameters including determination of physicochemical properties of tomato fruits. The storage experiment was conducted from October 24 to November 24, 2016 at Food Chemistry and Grain Science Laboratory.

\section{Experimental materials}

Two tomato varieties (Fetan and Melkashola) were collected from Somali Region Pastoral and Agro-pastoral Research
Institute. The fruits were selected based on physical attributes color, size, shape, absence of injuries, and freedom from disease. The selected fruits were transported to laboratory using clean purposely built plastic crates. Honeycomb, maize starch, garlic bulb, and Capsicum were purchased from local market in Harar city and transported to Food Science and Postharvest Technology Laboratory, Haramaya University.

\section{Experimental design}

A full $7 \times 2$ factorial design was used with two factors and three replications.

\section{Preparation of materials}

A fully mature green to breaker stage of tomato fruits were harvested and collected in plastic crate. While harvesting, proper manual harvesting procedure and technique as described by Mazumdar and Majumder [13]. Were followed. The tomato fruits were sorted, and graded by size. Then, tomato fruits were washed under running water and sub-divided into seven piles. 48 fruits in each pile and 672 of total fruit were used during storage period. All tomato fruits were disinfected by dipped in surface- sanitizer sodium hypochlorite ( $\mathrm{NaOCl}, 1 \%$ ) solution for $5 \mathrm{~min}$ and rinsed in water [14]. Then, the surface water was dried at ambient temperature before subsequent treatments.

The tomato fruits were dipped into prepared coating solution for $3 \mathrm{~min}$. The treated tomato fruit was stored at ambient temperature. Then from each treatment, three fruits were taken randomly at three days intervals within 30 days of storage time for determination of quality [15-17].The quality evaluations of stored fruit were carried out. The tomato juice was extracted using juice extractor (Model:SL-1304 STARLUX, made in China) and filtered by cheese cloth and the pulp was used for the estimation of chemical quality of tomato as described in Ranganna [18].

Preparation of emulsion: Emulsion was prepared as described in Muhammad et al., (2008). $3.50 \mathrm{~g}$ of beewax was taken in $250 \mathrm{~mL}$ conical flask and melted at $70^{\circ} \mathrm{C}$, heated continuously to attain the temperature of $85^{\circ} \mathrm{C}$ of melted wax. $4.40 \mathrm{~g}$ of stearic acid was added to melted beewax followed by addition of $1.50 \mathrm{~g}$ triethanolamine (TEA) by using magnetic stir. Then, $90.5 \mathrm{~mL}$ of distilled water which was pre-heated at the same temperature of $85^{\circ} \mathrm{C}$ and was added slowly with continued stirring for $10 \mathrm{~min}$. The prepared beewax was stored and cooled to ambient temperature.

Preparation of garlic bulb extract: Garlic bulb and free from disease was purchased from local market at Harar city and transported into laboratory. A $3 \mathrm{~kg}$ of garlic bulb was peeled and surface-sterilized by immersion in solution of sodium hypochlorite (NaOCl, $1 \%$ ) for $5 \mathrm{~min}$. The fruits were washed with distilled water. Then, garlic bulb was crushed by a clean laboratory mortar and pestle, and extracted by miller (Model:SL-1304, STARLUX, Made in China). The crushed garlic bulb was wrapped, squeezed by double layer cheese cloth. Then, the crude extract was filtered by Whatman No.2 paper and poured into a sterile $10 \mathrm{~mL}$ test tube and centrifuged at $1000 \mathrm{rpm}$ for $10 \mathrm{~min}$. The supernatant was filtered by Whatman 
No.1 filter paper. The extract was collected in bottle and stored in a refrigerator at $4^{\circ} \mathrm{C}$ until subsequent use [19].

Preparation of capsicum extract: Fresh green pepper, attribute of uniform size, color and freedom disease was purchased from local market at Harar city and transported into laboratory. A $3 \mathrm{~kg}$ of fresh, unblemished and healthy green pepper was removed the stack and cleaned by running water and surface-sterilized with sodium hypochlorite $(\mathrm{NaOCl}, 1 \%)$ for $5 \mathrm{~min}$. The fruits were washed with distilled water. Then, green pepper was sized with sterile kitchen knife, crushed by grinder extractor. The crushed capsicum was squeezed by hand and filtered by double cheese cloth and followed by Whatman's filter paper No.2. The extract was poured into a sterile 10 $\mathrm{mL}$ test tube and centrifuged at $1,000 \mathrm{rpm}$ for $10 \mathrm{~min}$. The supernatant was filtered through Whatman's filter paper No.1. The extract was collected in $200 \mathrm{~mL}$ of beaker and stored in a refrigerator at $4^{\circ} \mathrm{C}$ until subsequent use [20].

Preparation of coatings: Edible coatings were prepared according to method [21,22]. Maize (or corn) starch was purchased from supermarket. A $9.5 \%(\mathrm{w} / \mathrm{v})$ maize starch was prepared by mixing in distilled water. The starch slurry was heated at $70{ }^{\circ} \mathrm{C}$ for $20 \mathrm{~min}$, using magnetic stirrer (Model: heat-stir SB162, STONE STAFFORD SHIRE, SI15, OSA, UK). The dissolved suspension was filtered by cheese cloth and then the temperature was maintained at room temperature. Then, coatings were prepared by gently mixing $0.5 \mathrm{~mL}$ garlic bulb extract or capsicum extract and made up to $100 \mathrm{~mL}$ in distilled water. Beeswax (9.5\%) coatings were prepared by mixed 0.5 $\mathrm{mL}$ garlic bulb extract and capsicum extracts, respectively and made up $100 \mathrm{~mL}$ in distilled water. The solutions of coatings were maintained at $\mathrm{pH}$ of 5.6 using $1 \mathrm{~N} \mathrm{NaOH}$. The prepared coatings were stored in a refrigerator at $4{ }^{\circ} \mathrm{C}$ until used.

\section{Determination of physical attributes}

Weight Loss (\%): The weight loss (WL) was determined by using the methods of Gharezi, et al [23]. The tomato fruit weight loss was evaluated at 3 days-intervals by taking mass on laboratory weight balance (Model: KERN and Sorn GMbH, 440-45, $\mathrm{d}=0.1 \mathrm{~g}$, Germany). The percentage weight loss (\% WL) was calculated for each sampling interval using the formula given below.

$$
W L(\%)=\frac{W_{i}-W_{f}}{W_{i}} \times 100
$$
(g)

Where, $W_{i}$ initial weight, $W_{f}=$ weight the time of evaluation

Firmness: Firmness was determined by measuring the force required for using a standard probe 0 reading a handheld penetrometer (Model: FT 327, Effegi, Italy) was used for test. The registered force at the penetration was read as the firmness. A 5-mm flat head stainless-steel probe was used to penetrate the fruit and the value was expressed in kilograms force per square centimeter $\left(\mathrm{kg} \mathrm{f} / \mathrm{cm}^{2}\right)$ [24].

Decay Loss (\%): Decay loss was determined by [25]. Numbers fruits infected on each day of observation in relation to the numbers of fruits initially taken. Then, percent of decay loss was worked out by the formula given below.

$$
\text { Decay Loss }(\%)=\frac{\text { Total No. of infected fruits }}{\text { Total No. of fruit initial taken }} \times 100
$$

\section{Chemical analysis}

Total acidity (Citric Acid \%): Titratable acidity was determined by AOAC [26]. Method no. 942.15. Tomato fruits were taken from each treatment and chopped into small pieces and blended in an electric blender juice extractor (Model:SL-1304 STARLUX, made in China). The aliquot of tomato juice was filtered through cheesecloth and $10 \mathrm{~mL}$ was taken, centrifuged for $15 \mathrm{~min}$ at $1000 \mathrm{rpm}$. The titratable acidity expressed as percentage citric acid was obtained by titrating 5 $\mathrm{mL}$ filtrate of juice against standard $0.1 \mathrm{~N} \mathrm{NaOH}$ solution using phenolphthalein indicator until the end-point was reached to pink (persisting for $15 \mathrm{sec}$.). The titratable acidity was expressed as $\mathrm{g}$ of citric acid/100 mL of juice.

$$
A \text { cidity }(\%)=\frac{\text { Titre } \times \text { Normality of } \mathrm{NaOH} \times \text { meqwt }}{\text { Volume of juice taken } \times \text { Volume of filtrate }} \times 100
$$

Where: $0.1 \mathrm{~N} \mathrm{NaOH}$ is equivalent to $0.06404 \mathrm{~g}$ citric acid of milliequivalent weight (meqwt)

Ascorbic acid (Vitamin C): Vitamin C (ascorbic acid) content was determined by using titrimetric method with the titration of filtrate against 2, 6- dichlorophenol indophenol reagent as described in AOAC [26]. Method no. 967.21. Dye solution was prepared by dissolved a $50 \mathrm{mg}$ of 2,6-dichlorophenolindophenol containing $42 \mathrm{mg}$ of sodium bicarbonate with makeup distilled water to $100 \mathrm{~mL}$ flask. And $100 \mathrm{mg}$ of $\mathrm{L}$-ascorbic acid in a small volume of $3 \%$ metaphosphoric acid solution and make up to $100 \mathrm{~mL}$ with same solution the standard ascorbic acid solution was prepared.

An aliquot (slurry juice) of $10 \mathrm{~mL}$ tomato juice extract was diluted to $100 \mathrm{~mL}$ flask with $3 \%$ metaphosphoric acid and filtered through filter paper (Whatman No.2). The filtrate was titrated against the standard dye to a pink end-point (persisting for 15 second). Ascorbic acid content was expressed as mg per $100 \mathrm{~g}$ of fruit pulp.

$$
\text { Ascorbic Acid }(\operatorname{mgAA} 100 \mathrm{~g}-1)=\frac{\text { Titre } \times \text { dye factor } \times \text { Volume made up }}{\text { Volume of juice } \times \text { volume of filtrate }} \times 100
$$

Where: Dye fator (D.F) was prepared from standard dye solution $=\frac{0.5}{\text { Titre }}$

\section{Data collection}

The average ambient air temperature and relative humidity of the storage laboratory room were measured throughout the storage period. Over the entire period of the study the readings were taken in day time with 4 -hour intervals. Temperature was recorded using digital psychrometer (Model: ALNOR ${ }^{\circledR} 8612$ S/ N03057107). The relative humidity of the air was monitored using the same psychrometer that was used for temperature measurement. 


\section{Statistical analyses}

All data were collected for each treatment on tomato fruits at 3 days interval stored for 30 days and analyzed by the Statistical Analysis System (SAS). Significance tests were made by two-way factorial Analysis of Variance (ANOVA) model using for Completely Randomized Design (CRD). The results were reported as an average value of triplicate analysis (mean \pm SD). Differences between treatments were determined by Fisher's Least Significance Difference (LSD) method and statistical significance was accepted at $(\mathrm{P} \leq 0.05)$.

\section{Results and discussions}

Two varieties of tomato (Fetane and Melkashola) grown in the same geographic region and same season have been used studied for evaluating the parameters at 3 days-interval for 30 days Figures 1-3.

Tomato fruit stored at ambient temperature

\section{Temperature and relative humidity of ambient storage}

The average ambient air temperature and relative humidity of the storage room varied from 15.5 to $20.2^{\circ} \mathrm{C}$, and 55.5 to $67.3 \%$, respectively. Hardenburg, et al [27]. Mentioned that storage under relatively low temperature is the most efficient method to maintain quality of most fruit and vegetables due to its effects on reducing respiration rate, transpiration, ethylene production, physiological change and microbial activities. Hence, the ambient storage conditions did not have extremes of temperature and relative humidity that could affect the stored tomato fruits (Figure 4).

\section{Effects of coating materials and bio-extracts on physical quality of stored tomato fruits}

\section{Physical Parameters}

Decay loss: Figure 5 below presented data of decay loss of tomato fruit as affected by use of coating materials without bio-extracts. It shows that there was no visible sign of decay loss in both coated and uncoated tomato fruit by the $9^{\text {th }}$

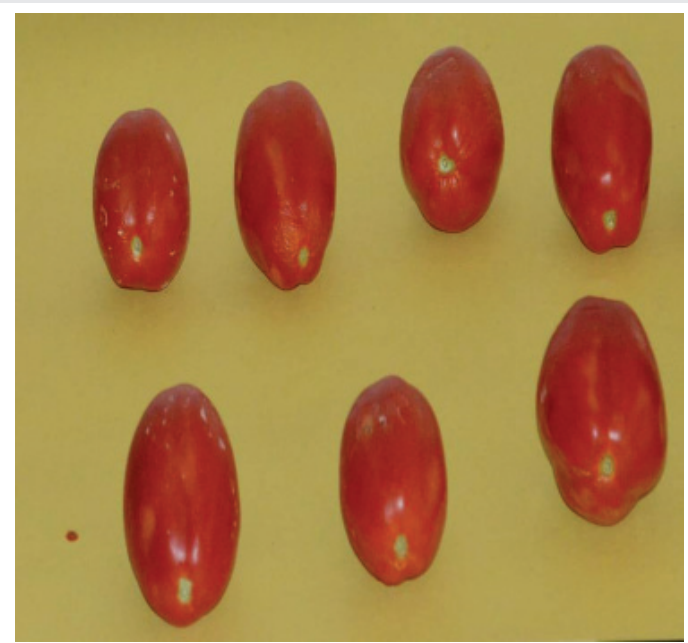

Figure 1: Tomato coating with Beewax plus capsicum extract stored at room temperature.

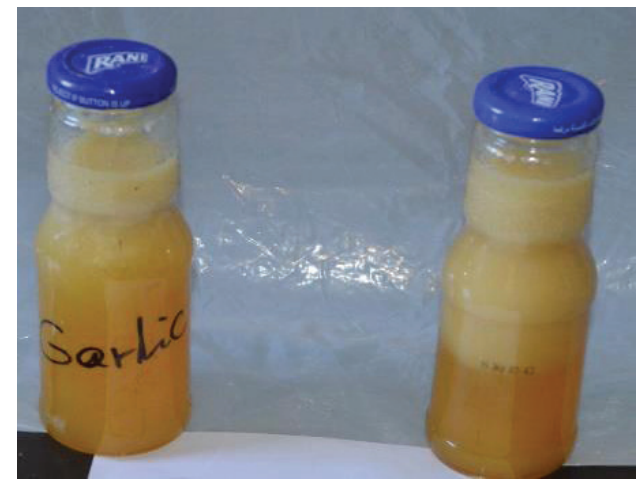

Figure 2: Garlic Extract.

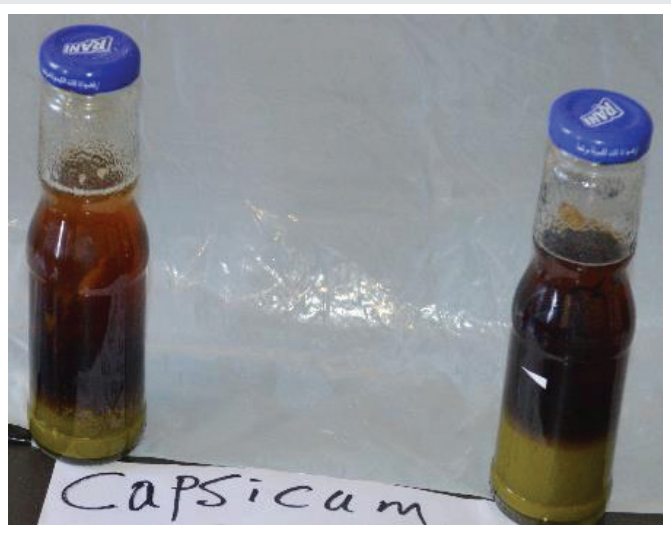

Figure 3: Capsicum Extract.

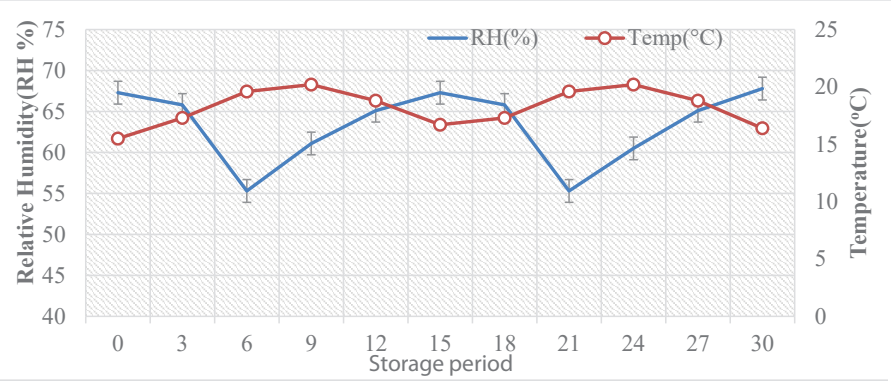

Figure 4: Ambient storage condition of tomato fruit.

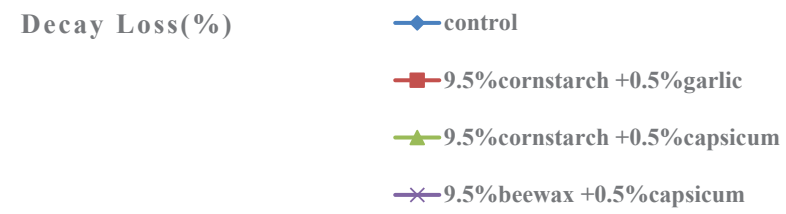

120

$\rightarrow-9.5 \%$ beewax $+0.5 \%$ garlic

100

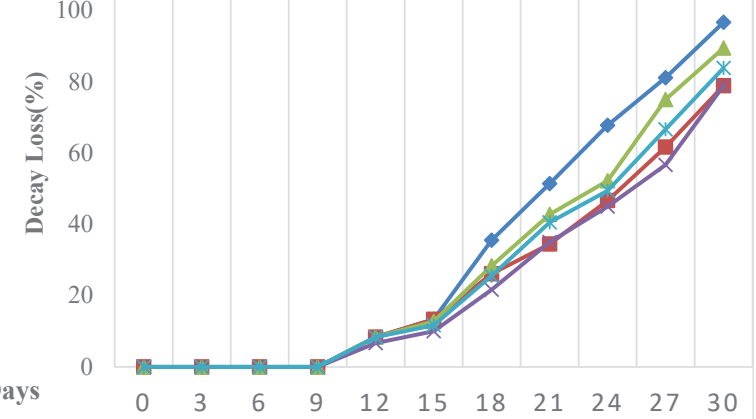

Storage Days 
day storage. Furthermore, both coated and uncoated fruits exhibited equal decay loss rates of 8.34 and $13.34 \%$ at $12^{\text {th }}$ and $15^{\text {th }}$ days of storage period, respectively.

However, after the $15^{\text {th }}$ day decay loss increased at different rates which were significantly $(\mathrm{P}<0.05)$ different from each other. From the $18^{\text {th }}$ day storage the decay losses were significantly $(\mathrm{P}<0.05)$ high in the control sample than the coated tomato fruit samples. The loss on day $18^{\text {th }}$ was $35.5 \%$ for control sample whereas it is very low in coated samples with 26.56 and $30.00 \%$, for those fruits coated with maize starch and beewax, respectively. The losses for $21^{\text {st }}, 24^{\text {th }}, 27^{\text {th }}$ and $30^{\text {th }}$ days exhibited similar trend of increment among the tomato fruit samples. Comparing the performance of two coating materials both resulted into significantly $(\mathrm{P}<0.05)$ lower decay losses as compared to control up to $30^{\text {th }}$ day. But same data showed that maize starch resulted in significantly $(\mathrm{P}<0.05)$ lower losses than beeswax for all storage periods. Similarly, Ali, et al [28]. Found that tomato fruit treated with 5 and $10 \%$ gum arabic coating and stored at $20^{\circ} \mathrm{C}$ showed reduce decay as compared to control tomato fruit.

Weight loss (\%): The data showing the impact of coating materials on weight loss is presented in Figure 6. Weight losses started soon after storage and the first record after 3 days showed of storage. There was no significant difference $(\mathrm{P}<0.05)$ among those values.

However, significant $(\mathrm{P}<0.05)$ difference in weight losses started to show up starting from day $6^{\text {th }}$ days of storage (i.e., $4.26 \%$ for control, $2.79 \%$ for maize starch and $3.31 \%$ for beewax). Similar, trends persisted throughout storage period in that samples coated with maize starch exhibiting significantly $(\mathrm{P}<0.05)$ lower weight loss as compared to samples coated with beewax. The maximum weight loss was $9.06 \%$ that was happened on day 30 for tomato fruits coated with maize starch. On other hand, the control sample exhibited significantly $(\mathrm{P}<0.05)$ the highest percentage of losses at every storage period with the highest (14.71\%) loss being on day 30.

Firmness: Data on firmness of stored tomato fruits at ambient temperature as influenced by coating materials are presented in figure 7. Comparing the effect of treatments, not as much difference was observed until day 12. Starting from day 15 samples, started to show significant differences up to day 24 , the highest records being samples of coated with maize starch. The lowest firmness value $(1.00 \mathrm{kgf} / \mathrm{cm} 2)$ was recorded for all the three samples on days 27 and 30. Generally, maize starch appeared to have a better performance than the beewax in regard to slowdown the textural change of tissues.

Agreement with the previous research work, gum arabic applied to green-mature tomatoes which were stored at $20^{\circ} \mathrm{C}$ and $80-90 \% \mathrm{RH}$ [28]. Retained their firmness better than control tomato fruit. As a biochemical process of fruit ripening progresses, the hydrolysis of pectins by pectin esterase and polygalacturonase enzyme activities can result in the depolymerization and shortening of pectin chain length which softens the fruits $[29,30]$.

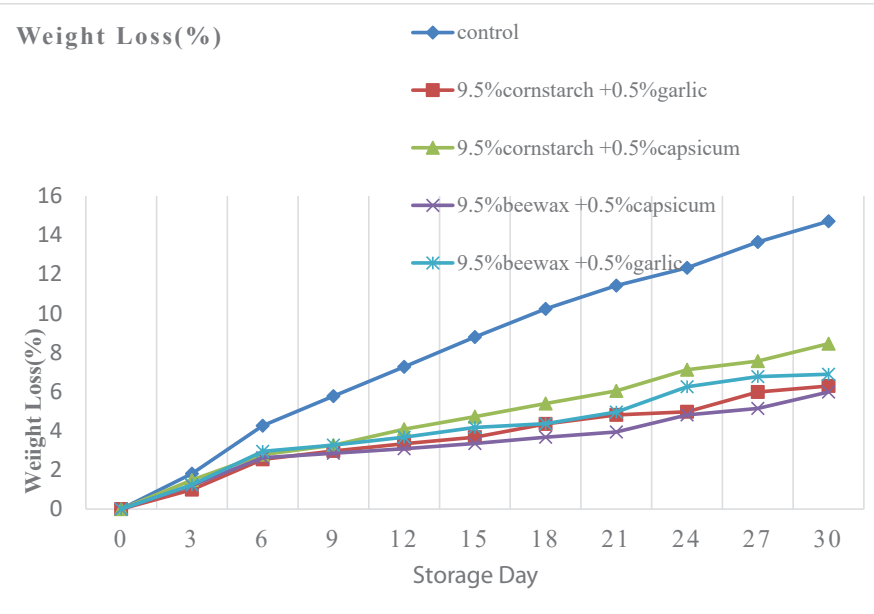

Figure 6: Weight Loss (\%)

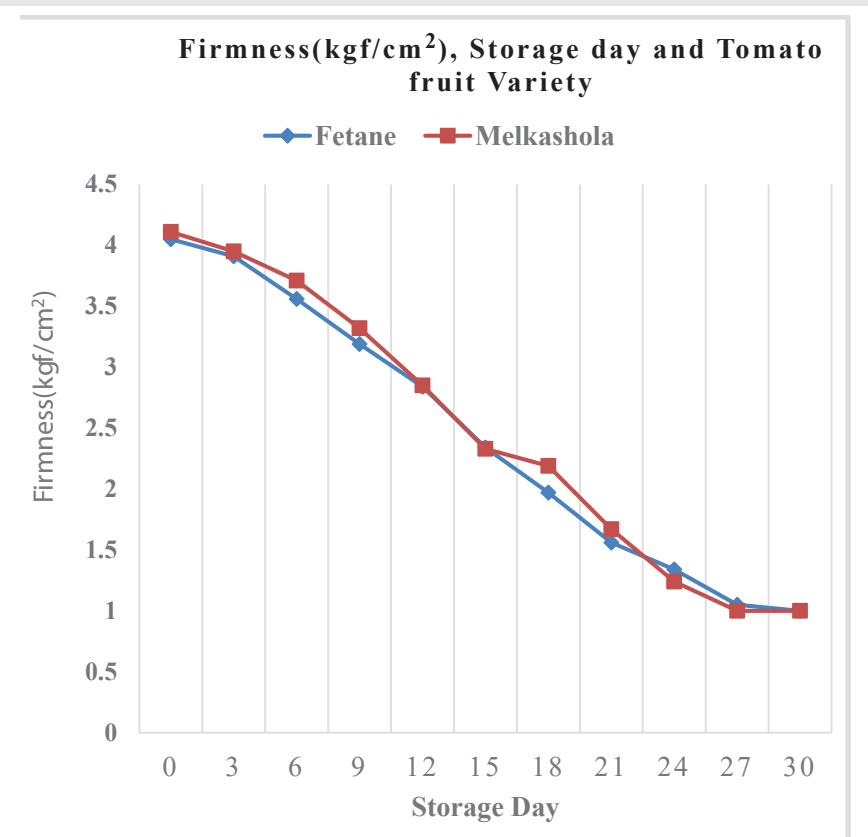

Figure 7: Firmness.

\section{Effects of coating materials and bio-extracts on physical quality of stored tomato fruits}

\section{Chemical parameters}

Titratable acidity: Titrable acidity of the stored tomato fruits also significantly affected by coating materials (Figure 8 ). The values were the same at beginning and started to show difference after that sample coated with starch exhibited higher TA values than those coated with beewax starting from day 18. Before that despite the differences between the values of the two groups it did not show any trend, one being higher at one stage and lower at another.

The control sample show that lower TA values than those of the coated fruits along the storage time except days 0 and 3. This can be explained by the fact that ripening process is faster and consequent conversion of acid into sugar and other substance is greater than coated fruits in which respiration and other biochemical activities were somehow slowed down. 
Generally, TA values were ranged from 1.09 day 0 to 0.24 on day 30 for both the control sample and coated sample with beewax while TA values for those of the coated by starch at same time was ranged from 1.09 to $0.36 \%$.

Regarding the interaction effect of coating materials with bio extracts show that samples treated with starch mixed with garlic and those treated with beewax with capsicum appeared to exhibit equal higher values than the rest of samples up to day 21 . The values after that showed no significance difference with the rest of the coated sample. The previous study agreement the titratable acidity (TA) values decreased with storage time in both the coated and uncoated fruit [28-30].

Ascorbic acid: The effect of coating materials on the ascorbic acid (AA) contents of the tomato fruits is shown in the data presented in (Figure 9. In most cases, the values do not show significance difference because of the coating materials and where differences were recorded they do not show consistent trend i.e. at one point a sample with one coating material displays higher value while at another it has a lower value. Generally, ascorbic acid content increased up to day18 and then gradually decreased with increasing storage time in both coated and the control sample.

Similarly, the ascorbic data did not show much-differences because of type of plant extracts all along the storage period. Only a few cases i.e. on day 9,15 , and 24 were there significant differences. Generally, the ascorbic acid contents of the control samples are lower than those of treated samples.

\section{Conclusions}

The use coating materials on the surface of the tomato fruits had helped to maintain the quality the fruits for longer storage time. For example, the decay loss has reduced to 85.05 and $93.34 \%$ when using maize starch and beewax coating materials, respectively as compared to 96.67 loss of the fruits stored with no coating. Similarly, the use coating materials has reduced the weight loss of the fruits from $14.71 \%$ in 30 days for uncoated samples to 9.06 and $10.51 \%$ of those with maize starch and beewax.

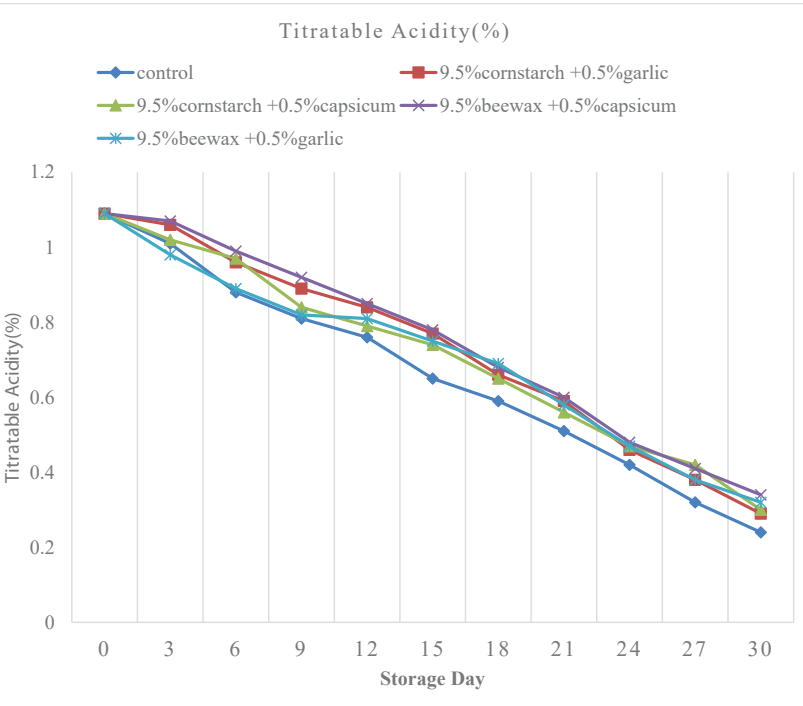

Ascorbic Acid vs Storage Day

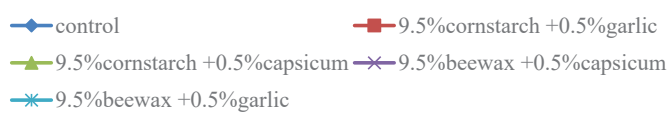

30

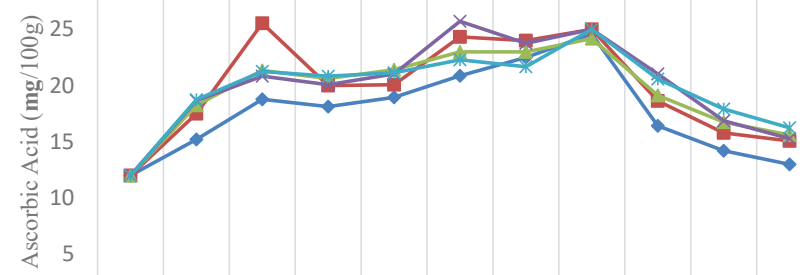

$\begin{array}{lllllllllll}0 & 3 & 6 & 9 & 12 & 15 & 18 & 21 & 24 & 27 & 30\end{array}$ Storage Day

Figure 9: Ascorbic Acid

The use of bio-extracts-capsicum and garlic extracts had significantly improved the performance of the coating materials by further reducing the decay losses to 84.17 and $81.39 \%$, respectively, and weight losses to 6.69 and $6.64 \%$ after 30 days of storage under ambient conditions. Generally, beewax combined with capsicum showed the lowest weight loss at all times followed by the starch mixed with garlic extracts. Similarly, beewax combined garlic and starch combined with capsicum have followed in performance order. Fruits subjected to the coating materials have shown better texture than uncoated fruits. The role of the coating materials also manifested in improving the marketability of the tomato fruits at longer storage periods, as compare to uncoated fruits.

The performance of the coating materials has been shown by storing down the changes such as, tirtable acid, and ascorbic acid. Thus, the tomato fruits are preserved more when coated than uncoated and beewax appeared to perform better than maize starch.

The study showed change in the tomato quality parameters under ambient conditions was largely dependent on variety and postharvest treatments. Fetane tomato fruits had slightly maintained better quality parameters than Melkashola in terms of percentage marketability, weight loss, and titratable acidity content. Whereas, Melkashola tomato fruits exhibited slightly better result in maintaining beta carotene and ascorbic acid content when as compared to Fetane tomato fruits. In generally, there was significance difference in physicochemical quality of tomato variety during storage period due to genotypic factor and respiration rate variability.

\section{Recommendations}

In developing country like Ethiopia which is still under struggle to ensure food security, losing a substantial amount food due to spoilage during postharvest handling of the produce is a disaster. Applying the result of this study can contribute a lot in saving a significant amount of fresh perishable tomato that perhaps lost in every household every producer and small-scale industry. Moreover, prolonging the shelf life of fresh tomato fruit can keep under control the problem faced to 
export fruit to other parts of the world. Based on this finding, therefore, the following points will be further work: Different concentration of edible coating materials with plant extract on fresh tomato fruit should be investigated. As the study was conducted at Haramaya University with specific climatic condition, further investigation on the variety of tomato fruit and kinds of decay loss that spoil fresh tomato fruit on the warmer parts of Ethiopia should be evaluated. Need to further study should be done on different dipping time with same coatings Stakeholders of the area need to be trained on the postharvest treatment and techniques to extending postharvest managements of horticultural commodity crops. Consumer acceptance for edible coated tomato should be investigated. Consumers are also required to be educated on the beneficial effects of edible coating application on fruits.

\section{Data availability}

The present study data used to support the findings of this study are available from the corresponding author upon request.

\section{Contribution of author}

Author contribution comprehended and designed the experiments, wrote and develop the proposal and data was collected by Desta Dugassa. The data was analyzed and wrote up final report by Desta Dugassa. The author read and approved the final manuscript as well.

\section{Acknowledgements}

I greatly valued support that from Haramaya University who provided the necessary information in the study suitability of bio coatings identify for cottage processing industry and storage coatings. Finally, greatly indebted to all our friends, and staff members indeed.

\section{References}

1. Tan HL, Thomas-Ahner JM, Grainger EM, Wan L, Francis DM, et al. (2010) Tomato-based food products for prostate cancer prevention: what have we learned?. Cancer Metastasis Rev 29: 553-568. Link: https://bit.ly/308PaRB

2. FAOSTAT (Food and Agriculture Organization Statistic) (2014) Statistica Database of Food and Agriculture Organization of the United Nation, Rome, Italy.

3. Thybo AK, Edelenbos M, Christensen LP, Sørensen JN, Thorup-Kristensen K (2008) Effect of organic growing systems on sensory quality and chemical composition of tomatoes. LWT J Food Science Technology 39: 835-843.

4. Ayari A, Achir N, Servent A, Ricci J, Brat P (2015) Development of a nutritiona profile predicting tool for fresh and processed tomato-based products. International Journal of Food Science and Technology 50:1598-1606. Link: https://bit.ly/2YC7P7y

5. Mutari A, Debbie R (2011) The effects of postharvest handling and storage temperature on the quality and shelf of tomato. African Journal of Food Science 5: 446-452. Link: https://bit.ly/30kfY10

6. Kitinoja L, Gorny J (2009) Storage Practices and Structures: Postharvest Technology for Fruit and Vegetable Produce Marketers. Postharvest Biology and Technology 1:20.

7. Souza EL, Sales CV, Oliveira CEV, Lopes LAA, Conceição ML, et al. (2015) Efficacy of a coating composed of chitosan from Mucorcircinelloides and carvacrol to control Aspergillus flavus and the quality of cherry tomato fruits Frontiers in Microbiology 6: 1-9. Link: https://bit.ly/2YxQ8Gb

8. Genanew T (2013) Effect of postharvest treatments on storage behavior and quality of tomato fruits. World Journal of Agricultural Sciences 9: 29-37. Link: https://bit.ly/3BZuvft

9. Seyoum TW (2002) The improvement of the shelf life of vegetables through pre-and postharvest treatment. PhD Dissertation University of Free State South Africa 270.

10. Mohammed K, Afework B (2015) Post-harvest loss and quality deterioration of horticultural crops in Dire Dawa Region, Ethiopia. Journal of the Saudi Society of Agricultural Sciences 15: 99-202. Link: https://bit.ly/3kk0UYj

11. Awole S, Woldetsadik K, Workneh TS (2011) Yield and storability of green fruits from hot pepper cultivars (Capsicum spp.). Africa Journal of Biotechnol 10: 12692-12700. Link: https://bit.ly/3n09UU3

12. Tekalign T (2005) Response of Potato to Paclobutrazole and Manipulation of Reproductive growth under Tropical Condition. PhD Dissertation Presented to University of Pretoria, South Africa 105

13. Mazumdar BC, Majumder K (2003) Methods on Physicochemical Analysis of Fruits. Daya Publishing House, New Delhi, India 33: 35-43.

14. Gustavo V, Jan J, Stella M, Jorge WC (2003) Principles and practices of small and medium-scale fruit juice processing: Handling and processing of fruit and vegetables by combined method in rural area. University of Florid, USA 106

15. Alcina BM, Shery LS, Maria F, de- Jesus Raposo MF, Manuel SCM (2010) Chemical dips and edible coatings to retard softening and browning of freshcut banana. International Journal of Postharvest Technology and Innovation 2: 13-24. Link: https://bit.ly/30fMdi2

16. Charu LM, Deba KD, Himjyoti D (2013) Development of a rice starch-based coating with antioxidant and microbe-barrier properties and study of its effect on tomatoes stored at room temperature. LWT Food Science and Technology, 50: 272-278. Link: https://bit.ly/3H7GXO3

17. Eric A, Ibok O, Patrick K (2015) Postharvest quality response of tomato (Lycopersicon esculentum, mill) fruits to different concentrations of calcium chloride at different dip times. American Journal of Food and Nutrition, 5: 1-8. Link: https://bit.ly/3D4iGpB

18. Ranganna S (1995) Handbook of analysis and quality control for fruits and vegetable products. Tata McGraw Hill Publishing Co. Ltd. New Delhi, India.

19. Jeum KH, Hye JY, Heesoo J, Dong JY, Sang MK, et al. (2015) Plant extract and application of volatile antifungal plant essential oils for controlling pepper fruit anthracnose by colletotrichum gloeosporioides. Plant Pathol J 31: 269-277. Link: https://bit.ly/30bnTgH

20. Soumya SL, Nair BR (2012) Antifungal Efficacy of capsicum frutescens L extracts against some prevalent fungal strains associated with groundnut. Journal of Agricultural Technology 8: 739-750. Link: https://bit.ly/3koeAl0

21. Ali A, Maqbool M, Ramachandran S, Alderson PG (2010) Gum arabic as anove edible coating for enhancing shelf-life and improving postharvest quality of tomato (Solanum lycopersicun L.) fruit. Postharvest Biology and Technology, 58: 42-47. Link: https://bit.ly/304kYqe

22. Lim R, Stathopoulos CE, Golding JB (2011) Effect of edible coatings on quality characteristics of sweet cherries. Int J Food Res 18: 1237-1241. Link: https://bit.ly/3bVcYdZ

23. Gharezi M, Neena J, Elnaz S (2012) Effect of Postharvest Treatment on Stored Cherry Tomatoes. J Nutr Food Sci 2:8. Link: https://bit.ly/3ESUo2u

24. Kumah P, Olympio NS, Tayviah CS (2011) Sensitivity of three tomato (Lycopersicon esculentum) cultivars - Akoma, Pectomech and power- to chilling injury. Agriculture and Biology Journal of North America 2: 799-805. Link: https://bit.ly/308XFMv

Citation: Fufa DD (2021) Suitability of bio-extracts with coating materials on physicochemical quality of tomato fruits (Solanum Lycopersicum L.) stored at ambient temperature. J Agric Sc Food Technol 7(3): 347-354. DOI: https://dx.doi.org/10.17352/2455-815X.000130 
25. Nirupama P, Neeta B, Gol TV, Ramana R (2010) Effect of postharvest treatments on physicochemical characteristics and storage life of Tomato (Lycopersicon esculentum mill.) fruits during storage. AmericanEurasian Journal Agricultural. and Environmental Science 9: 470-479. Link: https://bit.ly/3D1nCLW

26. AOAC (Association of Official Analytical Chemists) (2006) Method Association of Official Analytical Chemists. Official Methods of Analysis. 18th Edition. Washington Dc, USA.

27. Hardenburg RE, Warada AE, Wang CV (1986) The commercial storage of fruits, Vegetables, Florist and Nursery Stocks, Agriculture. Handbook No. 66, USDA Washington. D.C.Link: https://bit.ly/3CXpNjH
28. Ali A, Mehdi M, Peter GA, Noosheen Z (2011) Effect of gum arabic as an edible coating on antioxidant capacity of tomato (Solanum lycopersicum L) fruit during storage. Journal Postharvest Biology and Technology 76: 119-124.

29. Yaman O, Bayoindirli L (2002) Effects of an edible coating and cold storage on shelf-life and quality of cherries. Lebnsm. -Wiss. Und. Technol 35: 146-150.

30. AACC (American Association of Cereal Chemistry) (2000) Approved Methods of American Association of Cereal Chemists, Cereal Laboratory Methods. pp: 1100, 10th (ed.), Inc: St Paul, Minnesota, USA.
Discover a bigger Impact and Visibility of your article publication with

\section{Peertechz Publications}

\section{Highlights}

* Signatory publisher of ORCID

* Signatory Publisher of DORA (San Francisco Declaration on Research Assessment)

* Articles archived in worlds' renowned service providers such as Portico, CNKI, AGRIS, TDNet, Base (Bielefeld University Library), CrossRef, Scilit, J-Gate etc.

* Journals indexed in ICMJE, SHERPA/ROMEO, Google Scholar etc.

* OAI-PMH (Open Archives Initiative Protocol for Metadata Harvesting)

* Dedicated Editorial Board for every journa

* Accurate and rapid peer-review process

* Increased citations of published articles through promotions

* Reduced timeline for article publication

Submit your articles and experience a new surge in publication services (https://www.peertechz.com/submission).

Peertechz journals wishes everlasting success in your every endeavours. 